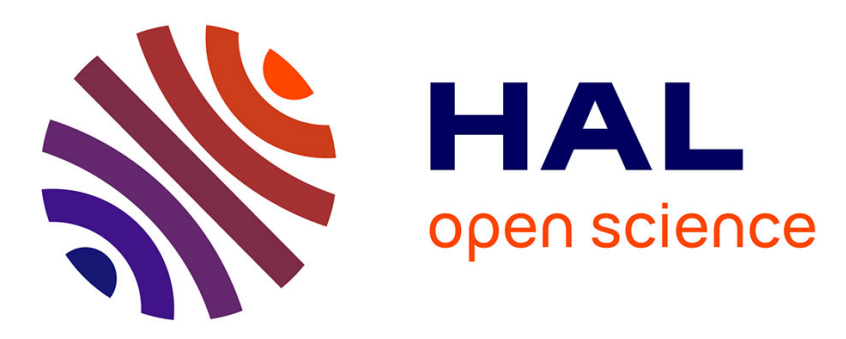

\title{
Mapping the use of public management tools in European public administration
}

\author{
Gilles Jeannot, Philippe Bezes
}

\section{To cite this version:}

Gilles Jeannot, Philippe Bezes. Mapping the use of public management tools in European public administration. Hammerschmid Gerhard, Van de Walle Steve, Andrews Rhys, Bezes Philippe, Public administration reforms in Europe, the view from the top, edward Elgar, pp.219-230, 2016. hal01340247

\section{HAL Id: hal-01340247 \\ https://hal-enpc.archives-ouvertes.fr/hal-01340247}

Submitted on 30 Jun 2016

HAL is a multi-disciplinary open access archive for the deposit and dissemination of scientific research documents, whether they are published or not. The documents may come from teaching and research institutions in France or abroad, or from public or private research centers.
L'archive ouverte pluridisciplinaire HAL, est destinée au dépôt et à la diffusion de documents scientifiques de niveau recherche, publiés ou non, émanant des établissements d'enseignement et de recherche français ou étrangers, des laboratoires publics ou privés. 


\section{Mapping the use of public management tools in European public administration Gilles Jeannot, Philippe Bezes}

\section{(This is a pre-print version longer the published paper)}

Jeannot Gilles, Bezes Philippe (2016) "Mapping the use of public management tools in European public administration", in Hammerschmid Gerhard, Van de Walle Steve, Andrews Rhys, Bezes Philippe, Public administration reforms in Europe, the view from the top, Edward Elgar, p. 219-230.)

The transformation of traditional management methods in public bureaucracies is one of the most significant aspects of the reforms influenced by New Public Management. These dynamics of change can be specifically well identified and analysed by paying attention to the ever-expanding diffusion of public management instruments in bureaucracies. From the most conventional accounting functions to the most sophisticated risk management or ISO quality standards, both business and public service management operates, within the framework of formal systems, through a large diversity of "management tools". Some are associated with computer software in order to settle global managerial architectures, others with new methods of government by targets and performance indicators while others, like staff appraisal, entail formal and structured procedures aimed at transforming human resources management. For decades, administrative reforms have continuously driven the development of management tools and spread their use throughout civil service structures. Instrumentation in public bureaucracies is then a major issue for research like in public policy (Hood, 1986; Lascoumes, Le Galès, 2007) and using a public management instruments framework offers a very insightful approach to analyse administrative changes in a comparative perspective (Bezes, 2007; Guillemot, Jeannot, 2013).

With this purpose, this chapter offers an initial but global picture emphasizing variations in the diffusion and perceived uses of public management tools in the 13 European countries covered by the Cocops Survey. The strong value of the Cocops survey is that it allows to understand changes in public management on the basis of a single input corresponding to a set of questions in which: top civil servants were asked to evaluate the use of the management tools employed in their national administrations. From this result the opportunity to measure the presence of a certain number of management tools in national civil services and policy sectors as well as the possibility to identify national and inter-sector variations.

In this chapter, we have also related, when relevant, this measurement to a few complementary items in order to better understand the varied uses of public management tools. They will be used to put in context the use of management tools. The first set offer a rough description of the global management within these administrations: to what extent and degree did top civil servants perceive their organisation to be focused on performance targets? The second set dimension is a basic assessment of their perceptions of improvement in the 
"performance" of their administrations, with respect to items very closely linked with the organisational dimension: to what extent and degree did top civil servants assess reforms to have led to 'less bureaucracy' and to a stronger staff motivation? Taken all together, the measure of management tools and these complementary items help to offer a broad comparative picture of how and to what extent NPM reforms have transformed public bureaucracies by diffusing new devices and tools.

\section{1) Management tools in European administrations}

\section{Use of management tools}

An approach centered on management tools offers an insightful perspective for describing changes in management practices: such view has been used in studies of innovation (Walker, 2007), in economic approaches to business reorganisation and its impact on employees (Greenan, Mairesse, 2006) or, more generally, in research in public policy (Lascoumes, Le Galès, 2007) and on how bureaucracies function (Hood, 1986; Hood and Margetts, 2007) oron the rise of performance-based management techniques (Hood, 2011). These tools flow between the public and private sector (Guillemot, Jeannot, 2013) and thereby gain recognition and legitimacy, although their implementation and impact differ from one sector to another. Moreover, they have acquired greater importance through their use by international bodies (OECD, EUPAN, etc.) to promote new "good management practices" in civil services, with the result that these tools become known through transfers from one country to another. Given the marked success of the instrument-based approach in enhancing our understanding of transformations in public policies (Lascoumes, Le Galès, 2007), it would seem particularly advisable to analyse administrative reforms from the same perspective (see Bezes, 2007).

Some surveys conducted by international bodies (OECD, 1993; OECD, 2005) have occasionally used the prevalence of management tools to measure the level of management practices in the administrations of different countries. However, these approaches did not show variations in the spread of these tools within states. Moreover, the questionnaires were often completed by a limited number of informants close to the centres of reform, which can introduce bias. Management tools have also been used as analytical material in a few academic studies in the US (Poister, McGwan, 1984; Brudney et al. 1999) and in Europe (Lægreid et al. 2006; Kuhlman et al., 2008; Torres et al., 2005; Jeannot, Guillemot, 2013). However, in these cases, such detailed approaches are limited to a single country. The advantage of the Cocops survey is that, by using the same questionnaire in every country, it provides a quantitative measurement of the spread of management tools in central government administrations in Europe. The list proposed consists of formalised and identifiable management tools and the answers come from large numbers of senior civil servants in each country.

The questionnaire includes an evaluation ("To what extent are the following instruments used in your organization?") which combines the rate of spread and the rate of use (Brudney, 1999), unlike other questionnaires that only ask whether or not the management tool exists (Laægreid et al; 2006; Jeannot, Guillemot, 2008). This option has the advantage of incorporating the notion of perceptions as to whether these tools are formal or actually implemented (Brunsson, 1982), but the disadvantage of introducing a greater degree of subjectivity. The part of the questionnaire about tools offered the option of responding "cannot assess", which avoided the need for respondents to give answers about tools unknown 
to them. This increases the robustness of the responses, but sharply reduces the number of responses used, in particular for the summary indicators. The method of analysis chosen is intentionally simple, based on the means of the answers on likert scales (1 to 7) for single questions. The tables included show all these means, though commentary is confined to the most marked differences, for which we have checked the statistical significance. The results of these significance tests are not given here.

The table below presents the mean figure for the different management tools for all the respondents in all the survey countries.

Table 1: the use of management tools

\begin{tabular}{|c|r|r|r|}
\hline Management tools & N & \multicolumn{1}{|c|}{ Mean } & \multicolumn{1}{c|}{ std dev } \\
\hline Performance appraisal & 6183 & 5.54 & 1.75 \\
Business/strategic planning & 6281 & 5.40 & 1.60 \\
MbO & 6267 & 5.30 & 1.71 \\
Codes of conduct & 6249 & 4.87 & 1.78 \\
Risk management & 5933 & 4.43 & 1.93 \\
Quality management systems & 6039 & 4.35 & 1.90 \\
Cost accounting systems & 5549 & 4.34 & 2.03 \\
Customer/user surveys & 6215 & 4.28 & 1.94 \\
Benchmarking & 6008 & 4.14 & 1.86 \\
Internal steering by contract & 5608 & 4.11 & 2.10 \\
Service points for customers & 5826 & 3.90 & 2.08 \\
Performance related pay & 6260 & 3.16 & 2.06 \\
\hline
\end{tabular}

"To what extent are the following instruments used in your organization?" Mean of a likert scale ${ }^{2 "}$ not at all =1 . to a large extent $=7$.

The first general observation is the ascendancy of management by objectives, the most basic tools of which - strategic planning (5.40) or management by objectives (5.30) - attain a high score across the board. The fact that the former has a more bureaucratic connotation, the latter a more managerial, makes no real difference. On the other hand, it is noteworthy that cost accounting systems (4.34) are much less prevalent in European countries, implying that there is a disconnect between the practice of management by objectives and the priorities associated with reforms in financial procedures focusing on costs . ${ }^{1}$

The second observation is that the most widespread tool in European countries is performance appraisal, which is a flexible way of translating management by objectives into human resource management terms. It is also noteworthy that two human resource management tools are positioned at opposite ends of the table, with performance appraisal being the most widely used tool, and performance related pay the least.

Tools that make beneficiaries and clients the focus of administrative practice - quality management systems (4.35) or customer/user surveys (4.28) - are less prevalent than strategic management tools. This may be linked with the fact that these approaches are only relevant if the administrative structure provides services to the public.

\footnotetext{
${ }^{1}$ The smaller number of replies on this item suggests that there may have been a problem in interpreting what the question was about.
} 
The tools least widely used in European countries are internal steering by contract and performance related pay, closely followed by benchmarking. These instruments are based on market type mechanisms stimulated by criticisms of bureaucracies, in particular in works that draw on the Public Choice school and are promoted by the OECD amongst others. It is significant that the spread of these practices has been moderate in Europe. These findings confirm that it is far from the case that governments, in their reforms, have all tended to prioritise the propagation of market type mechanisms (Pollitt, Bouckaert, 2011; Gingrich, 2011).

\section{The varied forms of management by objectives and by performance}

The COCOPS questionnaire also asked top civil servants to describe the contribution of management by objectives and performance to the operation of their departments, through a series of questions on the clarity of the goals set, the nature of the objectives and the uses of the systems: how widely they are communicated across the organisation but, above all, whether rewards or sanctions are associated with success or failure in achieving goals. The element of redundancy with tools in the questions reinforces also the robustness of the analysis.

Table 2: Goal focus

\begin{tabular}{|c|r|r|r|}
\hline Organisation & N & \multicolumn{1}{|c|}{ Mean } & \multicolumn{1}{c|}{ std dev } \\
\hline Our Goals are clearly stated & 6638 & 5.55 & 1.41 \\
Our goals are communicated to all staff & 6591 & 5.38 & 1.54 \\
We mainly measure outputs and & 6486 & 4.61 & 1.63 \\
$\begin{array}{c}\text { outcomes } \\
\text { We are rewarded for achieving our } \\
\text { goals }\end{array}$ & 6509 & 3.02 & 1.71 \\
$\begin{array}{c}\text { We face clear sanctions for not } \\
\text { achieving our goals }\end{array}$ & 6528 & 3.03 & 1.66 \\
\hline
\end{tabular}

"To what extent do the following statements apply to your organization?" Mean of answers on a likert scale "strongly disagree" $=1$; "strongly agree" $=7$.

Overall, management by objectives seems to be a strong feature of administrative organisations, since the 'goals clearly stated' item achieves the highest score (5.55) and the communication of these goals to staff also scores highly (5.3), a sign that the imperatives of management by performance are widely disseminated. By contrast, the uses of rewards or sanctions as incentives score significantly lower (3.02 and 3.03): this finding may reflect the fact that performance-related systems are loosely coupled with practices, or that the reformers are cautious about market type mechanisms based on individualised or financial incentives. 
Table 3: assessments of organisational performance

\begin{tabular}{|c|r|r|r|}
\hline Performance evaluation & \multicolumn{1}{|c|}{ N } & \multicolumn{1}{|c|}{ Mean } & \multicolumn{1}{c|}{ std dev } \\
\hline Cost and efficiency & 5977 & 4.68 & 1.35 \\
Service quality & 5967 & 4.76 & 1.32 \\
Internal bureaucracy reduction & 5902 & 3.90 & 1.45 \\
Staff motivation and attitudes towards work & 5919 & 3.97 & 1.45 \\
\hline
\end{tabular}

"Thinking about your policy area over the last five years how would you rate the way public administration has performed on the following dimensions ?" Mean of a likert scale : "deteriorated significantly = 1 ; "improved significantly $=7$ ".

The analysis is then rounded off with a few answers to questions on the evaluation of the performance of civil service departments over the last five years. Performance here should be understood as an assessment of the big priorities of departmental function. Here, we have focused on the issues most directly associated with the organisation itself: costs, quality of service, bureaucracy reduction and staff motivation. For the respondents to the Cocops overall, performance on costs and quality of service (what is delivered) receives a more positive assessment than internal operations (bureaucracy reduction and staff motivation). This would seem to put something of a dent in the idea of a "win-win" model of reforms, simultaneously favouring public servants and beneficiaries.

\section{2) Variations between types of organisation}

The COCOPS questionnaire obtained the views of senior civil servants situated at different hierarchical levels but also within different state structures: central ministries and agencies. With this perspective, it is possible to assess differences not only between countries, as do the surveys conducted by the OECD or EUPAN, but also between types of organisation within a single country. This also elucidates a subject that has been extensively explored, the specificity of agencies, and another less well-studied topic, the variations between policy sectors.

\section{The specificity of agencies}

Table 4 below compares the answers by respondents to the Cocops survey who work in central ministries with rose by respondents from agencies. The results show significant differences and confirm the specificity of agencies within states. 
Table 4: Variations between types of organisation

\begin{tabular}{|c|r|r|r|r|r|r|}
\hline & $\mathrm{N}$ & $\begin{array}{c}\text { Central } \\
\text { govt } \\
\text { ministry }\end{array}$ & $\begin{array}{c}\text { Stdde } \\
\mathrm{v}\end{array}$ & $\mathrm{N}$ & Agency & $\begin{array}{c}\text { Stdde } \\
\mathrm{v}\end{array}$ \\
\hline management tools & & & & & \\
\hline Tools mean & 1449 & 4.05 & 1.20 & 2185 & 4.85 & 1.10 \\
\hline Tools client & 2076 & 3.64 & 1.55 & 2963 & 4.58 & 1.49 \\
\hline Tools HRM & 2325 & 4.09 & 1.49 & 3213 & 4.68 & 1.56 \\
\hline Tools market & 2049 & 3.75 & 1.66 & 2921 & 4.42 & 1.57 \\
\hline Tools performance & 2357 & 5.09 & 1.52 & 3232 & 5.64 & 1.28 \\
\hline $\begin{array}{c}\text { Organization } \\
\text { Our Goals are clearly stated }\end{array}$ & 2604 & 5.26 & 1.50 & 3565 & 5.82 & 1.27 \\
\hline $\begin{array}{c}\text { Our goals are communicated to all } \\
\text { staff }\end{array}$ & 2578 & 5.06 & 1.64 & 3544 & 5.72 & 1.36 \\
\hline $\begin{array}{c}\text { We mainly measure outputs and } \\
\text { outcomes }\end{array}$ & 2514 & 4.29 & 1.66 & 3517 & 4.91 & 1.52 \\
\hline $\begin{array}{c}\text { We are rewarded for achieving our } \\
\text { goals }\end{array}$ & 2544 & 2.87 & 1.63 & 3506 & 3.21 & 1.75 \\
\hline $\begin{array}{c}\text { We face clear sanctions for not } \\
\text { achieving our goals }\end{array}$ & 2549 & 2.91 & 1.62 & 3522 & 3.20 & 1.66 \\
\hline
\end{tabular}

Summary indicators were produced, by establishing the mean of the means to the following groups of items. Tools mean : all tools .Tools customer: customer/user surveys; service points for customers; quality management systems. Tools human resources management (HRM) tools: performance related pay; staff appraisal interviews. Tools market: internal steering by contracts; benchmarking. .Tools performance: business/strategic planning; management by objectives

Consistent with the idea that the very existence of agencies reflects a neo-managerial objective, agencies are equipped with more management tools than central ministries, regardless of what tools are considered. Agencies would thus seem to be a vehicle of managerial modernisation, easily measured by the higher prevalence of the different categories of management tool. The most marked difference (one point) is in the use of customer orientated tools. This indicates the importance of agencies in service delivery. The replies to the questions on the use of performance objectives also reflects greater prevalence in their use in agencies, in particular as a basis for reward or sanction.

\section{The differences between public policy sectors}

While agencies have been a core field of research in numerous works on public administration, the variations in the intensity and impact of reforms between ministries and their public policy sectors have received less scholarly attention. There have been frequent sector-based case studies, but very few intersectorial comparisons. Yet it is apparent that there are significant differences in certain sectors, corresponding to specific government interventions and public policies. 
Table 5: Variations between sectors

\begin{tabular}{|c|c|c|c|c|c|c|c|c|c|c|c|c|}
\hline & \begin{tabular}{|c|} 
Employ \\
ment
\end{tabular} & $\begin{array}{l}\text { std } \\
\text { dev }\end{array}$ & Welfare & $\begin{array}{l}\text { std } \\
\text { dev }\end{array}$ & Finance & \begin{tabular}{l|} 
std \\
dev
\end{tabular} & $\begin{array}{c}\text { Justice } \\
\text { Order }\end{array}$ & $\begin{array}{l}\text { std } \\
\text { dev }\end{array}$ & \begin{tabular}{|c|} 
Trans- \\
port
\end{tabular} & $\begin{array}{l}\text { std } \\
\text { dev }\end{array}$ & Culture & $\begin{array}{l}\text { std } \\
\text { dev }\end{array}$ \\
\hline $\mathrm{N}$ & 600 & & 590 & & 150 & & 760 & & 630 & & 330 & \\
\hline Tools mean & 4.80 & 1.16 & 4.81 & 1.22 & 4.59 & 1.21 & 4.49 & 1.09 & 4.37 & 1.27 & 4.05 & 1.26 \\
\hline Tools client & 4.68 & 1.51 & 4.60 & 1.66 & 4.21 & 1.70 & 4.00 & 1.45 & 4.03 & 1.43 & 3.57 & 1.46 \\
\hline Tools HRM & 4.72 & 1.65 & 4.63 & 1.59 & 4.28 & 1.53 & 4.39 & 1.41 & 4.32 & 1.63 & 4.19 & 1.69 \\
\hline Tools market & 4.51 & 1.63 & 4.24 & 1.60 & 4.32 & 1.63 & 4.12 & 1.64 & 4.02 & 1.58 & 3.66 & 1.63 \\
\hline Tools performance & 5.64 & 1.34 & 5.53 & 1.33 & 5.52 & 1.35 & 5.46 & 1.36 & 5.19 & 1.50 & 5.12 & 1.53 \\
\hline Our goals are clearly stated & 5.68 & 1.36 & 5.69 & 1.33 & 5.83 & 1.36 & 5.59 & 1.35 & 5.31 & 1.51 & 5.28 & 1.55 \\
\hline Our goals are communicated to all staff & 5.67 & 1.46 & 5.59 & 1.45 & 5.59 & 1.55 & 5.38 & 1.46 & 5.10 & 1.61 & 5.09 & 1.62 \\
\hline We mainly measure outputs and outcomes & 4.94 & 1.52 & 4.76 & 1.60 & 4.93 & 1.60 & 4.40 & 1.61 & 4.40 & 1.65 & 4.35 & 1.63 \\
\hline We are rewarded for achieving goals & 3.41 & 1.80 & 3.04 & 1.72 & 3.13 & 1.78 & 2.76 & 1.57 & 3.04 & 1.79 & 2.66 & 1.59 \\
\hline We face clear sanctions for not achieving our goals & 3.16 & 1.66 & 3.00 & 1.59 & 3.34 & 1.78 & 2.73 & 1.51 & 3.03 & 1.67 & 2.71 & 1.54 \\
\hline
\end{tabular}

For all figures: mean of the answers on a likert scale 1 to 7 . Tools mean : all tools .Tools customer: customer/user surveys; service points for customers; quality management systems. Tools human resources management (HRM) tools: performance related pay; staff appraisal interviews. Tools market: internal steering by contracts; benchmarking. .Tools performance: business/strategic planning; management by objectives

The finding for the public finance sector is the most predictable, but not the most striking result. Given that respondents could tick several sectors of involvement, their answers relate not only to the ministry of finance but also to cross-cutting financial management functions in all departments. Finance is one of the policy sectors characterised by the most management tools and most exposed to mechanisms of management by performance. It leads the ranking for 'goals clearly stated', for the role of measurement by indicators ('mainly measure outputs and outcomes') and on the existence of sanctions for failing to achieve goals. This reflects stronger oversight of administrative activities relating specifically to the finance sector and associated with government priorities. Tighter monitoring of finances is a factor frequently highlighted in studies on public administration (Rainey, Bozeman, 2000).

More surprisingly, however, two other sectors are characterised by a higher prevalence of management tools than all the other sectors, and by greater exposure to management by objectives, whichever indicators are used: these are the Employment and Welfare sectors. The Employment sector, for example, tops the table for the presence of instruments of all types (customer orientated, human resources, market type or performance). It also leads the pack for the measurement of results ('measure outputs and outcomes') and for rewarding staff who meet their targets. In this sector, the strong (but relative) exposure to managerial systems can be explained by the fact that the departments are mostly organised into agencies, by the crucial and highly 'watched' nature of employment as an issue, but also by the striking spread of good practices in this domain, driven by the OECD and disseminated by the World Association of Public Employment Services (Weishaupt, 2010). As regards welfare departments, the findings of the survey are consistent with the very many studies that show that the professional bureaucracies present in this sector (Mintzberg, 1979) have been a particular target of neo-managerial reforms: either under explicit strategies to reduce their autonomy or because the reforms have favoured the reinforcement and professionalisation of the control and management functions in welfare states, thereby de facto transforming the interactions between managers and professionals (e.g., Exworthy, Halford, 1999; Farrell, Morris, 2003; Bezes, Demazière, 2012). If the two areas are compared with the other policy sectors, we also find that the greater prominence of management tools is particularly significant in the relatively large part played by tools associated with customer relations. This may reflect strategies to automate and rationalise relations with the disadvantaged populations targeted by welfare policies (Soss et al., 2011). 


\section{3) Variations between countries.}

Comparisons between countries need to be treated with caution. Because of the large institutional and cultural differences and the rarity of movement of senior civil servants between countries, the meanings ascribed to the questions, the frames of reference and the representations are likely to be different. Moreover, the references may not be comparable because of different trajectories and rates of reform. The variations in one country's relative positioning compared with others are therefore just as interesting as the absolute response rates. Here, we will comment only on the most marked trends (see Table 6 below), giving separate treatment to the countries emerging from post-communist transition (Estonia, Serbia, Hungary, Lithuania).

Table 6: Means per country and groups of countries, descending order of countries for the different questions

\begin{tabular}{|c|c|c|c|c|c|c|c|c|c|c|c|c|}
\hline & tools & tools client & tools HRM & $\begin{array}{c}\text { tools } \\
\text { market }\end{array}$ & $\begin{array}{l}2 \text { jols per- } \\
\text { formance }\end{array}$ & \begin{tabular}{||c|} 
Our goals \\
are clearly \\
stated
\end{tabular} & \begin{tabular}{|c} 
Our goals \\
are \\
communica \\
ted to all \\
staff
\end{tabular} & $\mid \begin{array}{c}\text { We mainly } \\
\text { measure } \\
\text { outputs } \\
\text { and } \\
\text { outcomes }\end{array}$ & \begin{tabular}{||c|} 
We are \\
rewarded \\
for \\
achieving \\
goals
\end{tabular} & $\begin{array}{c}\text { We face } \\
\text { clear } \\
\text { sanctions } \\
\text { for not } \\
\text { achieving } \\
\text { our goals } \\
\end{array}$ & $\begin{array}{c}\text { perform- } \\
\text { ance: less } \\
\text { bureau- } \\
\text { cracy }\end{array}$ & $\begin{array}{c}\text { perform- } \\
\text { ance: staff } \\
\text { moti-vation }\end{array}$ \\
\hline$\overline{\overline{\mathrm{UK}}}$ & 5.19 & 4.73 & \begin{tabular}{l||l||}
5.13 \\
\end{tabular} & 4.32 & 6.04 & 6.14 & 25.95 & \begin{tabular}{ll|}
4.98 \\
\end{tabular} & 3.39 & 3.61 & 4.05 & 3.59 \\
\hline Germany & 4.09 & 3.66 & 4.45 & 3.81 & 4.95 & 4.99 & 4.69 & 3.87 & 2.73 & 2.43 & 3.84 & 3.99 \\
\hline France & 3.96 & 3.56 & $4.75 \|$ & 3.78 & 4.89 & 4.90 & 4.66 & 3.92 & 3.01 & 2.70 & 3.76 & 3.30 \\
\hline Spain & 3.28 & 4.15 & $2.38 \|$ & 2.98 & 4.15 & 5.28 & 4.62 & 3.96 & 2.15 & 1.86 & 3.88 & 3.47 \\
\hline Italy & 4.48 & 3.96 & $4.39 \mid$ & 4.72 & 5.35 & 4.99 & 4.79 & 4.47 & 4.35 & 3.49 & 4.06 & 3.41 \\
\hline Norway & 4.70 & 4.52 & $4.28 \|$ & 3.66 & 5.69 & 5.46 & 5.47 & 4.51 & 2.77 & 2.71 & 4.25 & 4.66 \\
\hline$\overline{\mathrm{NL}}$ & 5.01 & 4.85 & 4.92 & 4.69 & 5.65 & 5.86 & 5.72 & 4.27 & 3.17 & 3.02 & 4.16 & 4.38 \\
\hline Austria & 3.96 & 3.65 & 3.50 & 3.68 & 5.22 & 5.43 & 5.24 & 4.54 & 2.61 & 2.35 & 3.94 & 3.78 \\
\hline Portugal & 4.33 & 4.46 & 3.52 & 4.25 & 5.46 & 5.58 & 5.51 & 4.78 & 2.50 & 3.20 & 4.44 & 3.23 \\
\hline Ireland & 4.37 & 4.13 & 3.57 & 3.52 & 5.73 & 5.82 & 5.41 & 4.34 & 2.19 & 2.64 & 4.12 & 3.38 \\
\hline Sweden & 5.28 & 4.40 & $6.34 \mid$ & 4.22 & 5.94 & 5.78 & 5.99 & 4.92 & 3.26 & 2.91 & 3.91 & 4.42 \\
\hline Denmark & 4.82 & 3.92 & 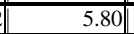 & 4.71 & 5.80 & 5.76 & 5.48 & 4.76 & 4.38 & 3.37 & 4.58 & $\overline{4.41}$ \\
\hline Finland & 4.97 & 4.27 & 4.96 & 4.95 & 5.94 & 5.69 & 5.70 & 4.61 & 3.06 & 2.33 & 3.50 & 4.61 \\
\hline
\end{tabular}

\begin{tabular}{|c|c|c|c|c|c|c|c|c|c|c|c|c|}
\hline Country Order & tools & tools client & tools HRM & |tools market| & $\begin{array}{l}\text { tools per- } \\
\text { formance }\end{array}$ & | goals clear & $\begin{array}{c}\begin{array}{c}\text { goals to } \\
\text { staff }\end{array} \\
\end{array}$ & output & rewarded & sanction & $\begin{array}{c}\text { 1ess bureau- } \\
\text { cracy }\end{array}$ & \begin{tabular}{|c} 
staff moti- \\
vation
\end{tabular} \\
\hline & Sweden & NL & Sweden & Finland & UK & UK & Sweden & UK & Denmark & UK & Denmark & Norway \\
\hline & UK & UK & Denmark & Italy & Finland & NL & UK & Sweden & Italy & Italy & Portugal & Finland \\
\hline & NL & Norway & UK & Denmark & Sweden & Ireland & NL & Portugal & UK & Denmark & Norway & Sweden \\
\hline & Finland & Portugal & Finland & NL & Denmark & Sweden & Finland & Denmark & Sweden & Portugal & NL & Denmark \\
\hline & Denmark & Sweden & NL & UK & Ireland & Denmark & Portugal & Finland & NL & NL & Ireland & NL \\
\hline & Norway & Finland & France & Portugal & Norway & Finland & Denmark & Austria & Finland & Sweden & Italy & Germany \\
\hline & Italy & Spain & Germany & Sweden & NL & Portugal & Norway & Norway & France & Norway & UK & Austria \\
\hline & Ireland & Ireland & Italy & Germany & Portugal & Norway & Ireland & Italy & Norway & France & Austria & UK \\
\hline & Portugal & Italy & Norway & France & Italy & Austria & Austria & Ireland & Germany & Ireland & Sweden & Spain \\
\hline & Germany & Denmark & Ireland & Austria & Austria & Spain & Italy & NL & Austria & Germany & Spain & Italy \\
\hline & Austria & Germany & Portugal & Norway & Germany & Germany & Germany & Spain & Portugal & Austria & Germany & Ireland \\
\hline & France & Austria & Austria & Ireland & France & Italy & France & France & Ireland & Finland & France & France \\
\hline & Spain & France & Spain & Spain & Spain & France & Spain & Germany & Spain & Spain & Finland & Portugal \\
\hline
\end{tabular}

\begin{tabular}{|c|c|c|c|c|c|c|c|c|c|c|c|c|}
\hline UK,N,NL,S,Fi,Dk & \begin{tabular}{l|l|}
4.999 \\
\end{tabular} & \begin{tabular}{c|c|}
4.45 \\
\end{tabular} & \begin{tabular}{|c|}
5.24 \\
\end{tabular} & \begin{tabular}{l|l|}
4.42 \\
\end{tabular} & $\begin{array}{l}5.85 \\
\end{array}$ & \begin{tabular}{|c||}
5.78 \\
\end{tabular} & \begin{tabular}{l||}
5.72 \\
\end{tabular} & \begin{tabular}{|l|l|}
4.67 \\
\end{tabular} & \begin{tabular}{|c|}
3.34 \\
\end{tabular} & \begin{tabular}{ll|}
2.99 \\
\end{tabular} & \begin{tabular}{l|l|}
4.08 \\
\end{tabular} & 4.34 \\
\hline F D Au & 4.00 & 3.62 & 4.23 & 3.76 & 5.02 & 5.11 & 4.86 & 4.11 & 2.78 & 2.49 & 3.85 & 3.69 \\
\hline$\overline{\mathrm{I}, \mathrm{P}, \mathrm{E}}$ & 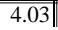 & 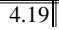 & 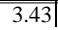 & 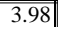 & $\mid 4.99$ & 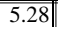 & 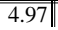 & 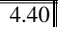 & 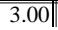 & $\mid 2.85$ & 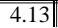 & $\mid+3.37$ \\
\hline
\end{tabular}

For all figures : mean of the answers on a likert scale 1 to 7 . Tools mean : all tools .Tools customer: customer/user surveys; service points for customers; quality management systems. Tools human resources management (HRM) tools: performance related pay; staff appraisal interviews. Tools market: internal steering by contracts; benchmarking. .Tools performance: business/strategic planning; management by objectives 
Countries engaged in long-term reforms (Great Britain, Sweden, Denmark, Norway, Ireland): varieties of NPMization

Studies on the implementation of New Public Management have clearly shown that Great Britain, on the one hand, and the Northern European countries (Netherlands and Scandinavia), on the other, were the countries most affected by neo-managerial reforms (Hood et al. 2004; Pollitt, Bouckaert, 2011; Goldfinch, Wallis, 2009). It therefore comes as no surprise to find these countries topping the table on the different items that describe the operation of administrative departments. Measured in terms of equipment with management instruments, Sweden, Great Britain and the Netherlands would seem to be the countries most committed to NPM reforms. Finland and Denmark come next, whereas Ireland and Norway are slightly behind, in an intermediate position. Norway's position reflects the description generally given of its implementation of NPM (Christensen, Lægreid, 2007), often standing halfway between Sweden and Great Britain, on the one hand, and France and Germany, on the other.

However, beyond the level of equipment in management instruments, the survey fills in the gaps regarding the varieties of NPMisation. This is because the relative positions of the different countries vary significantly from one domain to another. Great Britain would seem to be involved in all the areas covered in this chapter, but it achieves the highest score on the existence of clear objectives, measurement of outputs and outcomes and sanctions for failing to achieve goals. On the other hand, it is striking the UK is outshone by several countries (Finland, Denmark, Netherlands) as regards the prevalence of market type instruments and in the use of performance instruments as incentives, measured by the question 'we are rewarded for achieving goals' (Denmark, Italy). While Britain was initially held up as the model for the implementation of organisational economics (public choice, agency theory, Self, 1993), this may have become attenuated over time with opposing directions of reform (for an overview of these pendulum switches, Wegrich, 2011) and, conversely, Scandinavian countries (Sweden, Denmark, Norway) may perhaps have been more engaged in approaches based on internal incentives than initially thought (Hansen, 2011, 127).

Sweden's position, in particular, is characterised by a stronger engagement in the human resources aspect: it is equipped with more HR tools than the other countries and is characterised by a positive assessment of trends in staff motivation. This observation is perhaps explained by the recurring emphasis on processes of decentralisation in human resource management, beginning in the first half of the 1980s (Ibsen et al., 2011, 2304), which give agencies a high degree of autonomy. In addition, while 'clarity of objectives' scores lower than in Great Britain, the extent to which these are communicated to staff and the measurement of outputs and outcomes are the same. Denmark is close to Sweden on questions of human resources. However, that country is characterised above all by a particularly marked commitment to market type mechanisms and by the use of rewards and sanctions associated with the attainment of results. This latter feature may perhaps be explained by the influence of contracts between ministries and agencies, an approach instituted in the early 1990s (Binderkrantz, Christensen, 2009). For its part, Finland is characterised by the strong presence of market type instruments, as well as management by performance. The Netherlands stands out for the prevalence of customer-orientated and market type instruments (in particular internal contracts), but also for a very high incidence of performance tools. The Netherlands also scores high on clarity of objectives and their dissemination to all staff. Here, we see priorities contained in the first pro-market reforms of 1982: the development of 'contract management', the strong promotion of agencies in the first reform in the 1990s and the 
introduction in 2001 of the "outcome based" budget system, christened VBTB ("from policy budgeting to policy accounting')(Yesilkagit, de Vries, 2004; Noordegraaf, 2009, 265-266).

As regards their assessment of trends in organisational function (scale of bureaucracy, staff motivation), the British respondents are less optimistic overall than their counterparts in the Scandinavian countries, in particular the Danish and Norwegians. For their part, senior civil servants in Sweden are more sceptical about bureaucracy reduction than staff motivation. Amongst the Norwegian respondents, optimism about these two factors contrasts with their qualified assessment of the use of management tools. In Finland, there seem to be sharp contrasts in the impact assessments: while their perception of staff motivation is the most positive of the European countries, along with Norway, they are the most sceptical of all the European countries about reductions in bureaucracy.

\section{Modest differences among continental countries, France, Germany, Austria}

France and Germany seem very broadly similar from a European perspective. These two countries are close together, at the bottom of the table, for most items. The small differences observed are not significant, especially as the sampling decisions, which excluded regional state services in France (very well equipped with management tools) and in Germany included the equally well equipped employment agency, create an imbalance to France's detriment. France and Germany are among the countries with the lowest prevalence of management tools. They also appear to score relatively poorly in the clarity and communication of objectives, as well as in the measurement of outputs and outcomes. On the other hand, both countries are placed nearer the middle in Europe with regard to the existence of reward mechanisms when targets are met (especially France) and, to a lesser degree, the imposition of sanctions associated with the failure to achieve goals. In addition, senior German civil servants are less pessimistic about staff motivation than their French counterparts, who are particularly gloomy in their assessment of this factor. However, senior civil servants in both countries are the least inclined in Europe to see bureaucracy as having diminished.

Austria's position is not very different from those two countries, and corresponds to a picture of cautious commitment to reforms that are compatible with the old bureaucratic system (Hammerschmid, Meyer 2005).

While comparing the orders of the countries has the virtue of highlighting differences, we must be careful not to ignore the scale of those differences. If we compare the three continental countries with the four countries most committed to reform (Great Britain, Sweden, Netherlands, Denmark), the difference in the responses is in the region of one point on an evaluation scale running from 1 to 7 (one point on the mean for management tools; 1.2 on HR tools and the assessment of quality improvements, and less than one point on the other items). This differential is less than the gap between different types of tools across Europe (up to two points), which puts into perspective the weakness of the involvement in reform in these countries. 


\section{Hesitations in the Southern countries}

In typologies relating to the development of NPM, the Southern countries are often associated with the idea of failure (Kickert, 2010). However, there seem to be contrasts between the findings for Spain, on the one hand, which is one of the countries least engaged in reforms, and Italy and Portugal, whose top executives display a more marked and resolute commitment and which, in certain areas, can resemble the northern European countries.

Spain thus scores very low on all the tools, and on the existence of rewards and sanctions associated with attainment or non-attainment of results. The only counter example is the presence of customer orientated tools, where Spain stands somewhere in the middle and is associated with a high proportion of responses relating to one-stop shops. The size of the gap between Spain and the most committed countries is very marked, in some cases as much as two points.

Italy ranks high on the use of market type tools, but also on the existence of rewards and sanctions associated with results. The presence of incentive mechanisms in the use of performance management systems is interesting, given that tools for management by objectives appear less developed in Italy than in the European countries most committed to these reforms, though nonetheless greater than in Spain, France or Germany. Academic work confirms the importance of the performance reforms in Italy, especially since 2007 with a reform in the budgetary procedure and the introduction of targets and performance indicators (Ongaro, 2009, 2011). A possible explanation of the higher score for the Italian replies on the use of incentives (rewards/sanctions) in performance instruments may be the strong rhetoric prevalent in Italy on manager accountability, but also the power and the scale of spoils system practices, particularly since the 2000s. For its part, Portugal is very well equipped in customer-orientated tools and perceptions of the reduction in bureaucracy in the Portuguese administration are positive. This may be linked with the importance of what certain authors (Magone, 2011, 770-771) call the 'New Governance Agenda' implemented by different governments over two decades and reinforced in the 2000s: it is characterised by the introduction of numerous instruments focusing on quality management and citizen responsiveness (one-stop shops, citizens' rights charters, complaints book), and by Portugal's objective of building a citizen-friendly public administration (Magone, 2011, 771).

However, unlike the countries that regularly top the table on all items, Italy and Portugal are associated with relatively low rankings on other subjects such as human resources tools (for Portugal) and especially the assessment of (for both countries).

The transition countries: Lithuania, Estonia, Hungary, Serbia

Table 7: mean per country

\begin{tabular}{|c|c|c|c|c|c|c|c|c|c|c|c|c|}
\hline & tools & tools client & tools HRM & $\begin{array}{c}\text { tools } \\
\text { market }\end{array}$ & $\begin{array}{l}\text { tools per- } \\
\text { formance }\end{array}$ & $\begin{array}{c}\text { Our goals } \\
\text { are clearly } \\
\text { stated }\end{array}$ & $\begin{array}{c}\text { Our goals } \\
\text { are } \\
\text { communica } \\
\text { ted to all } \\
\text { staff }\end{array}$ & $\begin{array}{c}\text { We mainly } \\
\text { measure } \\
\text { outputs } \\
\text { and } \\
\text { outcomes }\end{array}$ & $\begin{array}{c}\text { We are } \\
\text { rewarded } \\
\text { for } \\
\text { achieving } \\
\text { goals }\end{array}$ & $\begin{array}{l}\text { We face } \\
\text { clear } \\
\text { sanctions } \\
\text { for not } \\
\text { achieving } \\
\text { our goals }\end{array}$ & $\begin{array}{c}\text { perform- } \\
\text { ance: less } \\
\text { bureau- } \\
\text { cracy }\end{array}$ & $\begin{array}{c}\text { perform- } \\
\text { ance: staff } \\
\text { moti-vation }\end{array}$ \\
\hline Estonia & 4.53 & 4.35 & 4.52 & 3.87 & 4.92 & 5.70 & \begin{tabular}{l|l}
5.49 \\
\end{tabular} & 4.94 & 4.05 & 3.13 & 3.94 & 3.72 \\
\hline Serbia & 3.91 & 3.70 & 3.37 & 3.98 & 4.95 & 5.61 & 5.36 & 5.34 & 3.23 & \begin{tabular}{|l|}
4.19 \\
\end{tabular} & 3.69 & 4.08 \\
\hline Hungary & 3.49 & 3.95 & 3.46 & 3.72 & 4.07 & 5.44 & 5.29 & 4.18 & 2.85 & 4.31 & 4.05 & 4.14 \\
\hline \begin{tabular}{|l} 
Lithuania \\
\end{tabular} & 4.94 & 5.05 & 4.42 & 4.58 & 5.81 & 6.20 & 6.08 & 5.31 & 2.99 & 3.93 & 3.77 & 4.28 \\
\hline
\end{tabular}

See upwards 
For the countries that have been going through processes of democratic transition since the 1990s, administrative reform has been part of a more recent history whose development differs markedly from the other countries. External influences (role of the IMF, impact of conditions associated with EU entry) here are much stronger and more direct; certain changes have been more radical. For this reason, direct comparisons with the previous countries seem of little relevance, and it is preferable to present the findings separately.

Lithuania shows extremely strong commitment to all components of the reform - the highest rate of equipment in management tools and focus on objectives - whereas the use of organisational indicators to reward or sanction is relatively weaker. Moreover, while this country's top civil servants have a less optimistic view than those of other countries on cost improvements or bureaucracy reduction, they are also the ones who rate staff motivation most highly. Estonia displays comparable characteristics, though slightly less marked, with two specific features: marked use of management tools to reward or sanction and the lowest rating of staff motivation. Serbia's response profile is very different: fewer management tools than Estonia or Lithuania (specifically customer focused or HRM tools), together with less commitment to objectives than in those two countries (goals clearly stated and communicated to staff), but a slightly greater use of indicators to reward or sanction.). For its part, Hungary clearly emerges as one of the countries least committed to reform. It stand out on two items: the existence of sanctions when results are not achieved and a.

\section{Conclusion}

This analysis of the data on the basis of mean figures alone constitutes an initial step, which will of course have to be taken further with more sophisticated analyses. However, certain striking findings already emerge.

The first finding of the Cocops survey is that the spread of market type mechanisms, inspired by Public Choice, has been limited in Europe. The argument is fairly robust for two reasons. First, it can be confirmed through two questions formulated in different terms: the question on tools and that on the existence of individualised practices (rewards/sanctions) linked with performance instruments. If we apply the classic distinction made by Christopher Hood (1991) and Peter Aucoin (1990) between tools originating in managerialism and both originating in Public Choice, we can see that the former (strategic planning, management by objectives) are much more widespread than the latter (benchmarking, performance related pay, steering by contract). In addition, individualised uses of performance tools (rewards/sanctions) are not the most widespread and do not necessarily lead the rankings in the most NPMised countries, a sign that the use of negative and positive incentives can be linked with very different types of reasoning, and does not not necessarily reflect a hearts and minds conversion to market ideology. In addition, the variations between categories of tools within a single country (which can be as high as two points) are often greater than the variations observed for a single tool between two countries (of the order of one point). This difference no longer endorses the old contrast between Great Britain, seen as the model for NPMisation countries, and the other European countries, because Great Britain is surpassed on two of these items by Denmark and Italy. The reality is therefore more mixed. Moreover, the most widely implemented tools, such as strategic planning or management by objectives, are those that can be just as meaningful in a bureaucratic tradition as in a NPM perspective, which therefore argues for a degree of continuity. 
The second finding, on variations between countries, confirms the classic contrast between northern and southern countries, but significantly alters the position within these groupings. The most surprising result is the split in the southern countries group between Spain which, in terms of equipment in management tools, seems one of the countries least engaged in the reforms, and Italy and Portugal, which show marked commitment in certain areas. The survey also provides some initial information on the transition countries, which merits further exploration in order to elucidate the particular circumstances of these countries. If we compare the main specificities of the countries, as suggested by the data and in academic monographs that analyse the reforms underway, we find that it is far from the case that these specificities coincide with the most recent periods of reform, and that they may reflect the long-term impact of earlier or repeated reforms, or even of national traditions that predate NPM.

The third finding is the existence of significant internal variations within countries, linked both with organisational types but also with policy sectors. While this in part reflects the specific impact of agencies, for which the findings differ significantly from those of central departments, what is newer is the largely equivalent effect we find associated with the policy sectors of organisations. This is true of finance departments, where monitoring is tighter because of the associated economic factors, but also of the employment and welfare sectors, where we see the strong impact of management rationalisation policies affecting, in particular, the relations with the beneficiaries of those policies - jobseekers or welfare recipients. 


\section{References}

Aucoin P. (1990), «Administrative Reform in Public Management: Paradigms, Principles, Paradoxes and Pendulums », Governance, 3, 2, 115-137.

Bezes P. (2007), "The Hidden Politics of Administrative Reform : Cutting French Civil Service Wages With a Low-Profile Instrument ", Governance. 20, 1, 23-56.

Bezes P., Demazière D. (2012). "Introduction to the Special Issue.New Public Management and Professionals in the Public Sector. What New Patterns Beyond Opposition?", Sociologie du Travail in English, 54, suppl. 1, October, 1-11.

Binderkrantz A.S., Christensen J.G. (2009). «Delegation without agency loss ?The use of performance contracts in Danish central government", Governance, 22, 2, 263-293.

Brudney J. 1., Hebert T., Wright D. S. (1999), "Reinventing government in the American States; Measuring and explaining administrative reform", Public administration review, 59, 1, 19-30.

Brunsson N. (1982). The organization of Hypocrizy, The decision and action in organizations, John Wiley and son.

Christensen J. (2009). "Danish public management reform before and after NPM", in Goldfinch S. Wallis J. L., International handbook of public management reform, 262-278.

Christensen T., Lægreid P. (2007). Transcending new public management, the transformation of public sector reforms, Aldershot, Ashgate.

Exworthy, M., Halford, S. (Eds.) (1999). Professionals and the New Managerialism in the Public Sector.Open University Press, Buckingham.

Farrell, C., Morris, J. (2003). "The "Neo-Bureaucratic" State: Professionals, Managers and Professional Managers in Schools, General Practices and Social Work".Organization10, 129-156.

Gingrich,

Goldfinch S., Wallis J. (2010)."Two myths of convergence in public management reform”, Public administration, 88, 4, 1099-115.

Greenan N., Mairesse J. (2006). "Réorganisations, changementsdu travail etrenouvellement des compétences", Revue économique, vol. 57, n 6, novembre p. 1177, 1203

Guillemot D., Jeannot G. (2013). "Modernization and bureaucracy in France: Assessing State administration by privatesector standards", Revue française de sociologie, 54-1, 76-101.

Hammerschmid G., Meyer R. (2005). "New public management in Austria: local variations on a global theme?", Public administration, 83, 3, 709-723.

Hansen H.F. (2010). "NPM in Scandinavia", in Christensen T., Laegreid P., The Ashgate Research Companion to New Public Management, 113-129.

Hood, C. (1986). The tools of government, Chatham, Chatham House.

Hood C. (1991). "A public management for all seasons", Public administration, 69, 3-19.

Hood C., Margetts H. (2007). The tools of government in the Digital Era, Palgrave Macmillan, 2007

Hood, C., James O., Peters B.G., Scott, C., eds. (2004). Controlling Modern Government. Variety, Commonality and Change, Edward Elgar.

Hood, C. (2011). The Blame Game. Spin, Bureaucracy and Self-Preservation in Government, Princeton University Press.

Ibsen C. L., Larsen T.P., Madsen J.S. \& Due J. (2011). 'ChallengingScandinavianEmployment Relations: the Effects of New Public Management Reforms', The International Journal of Human Resource Management, 22, 11, 2295-2310

Jeannot G., Guillemot D. (2013). "French public management reform: an evaluation", International journal of public sector management, 26, 4, 283-297. 
Kikert W.J.M. (2010). "Public management reform Continental Europe: National Distinctiveness" in Christensen T., Lægreid P., The Ashgate Research Companion to New Public Management, Ashgate, 2010.

Kuhlmann S., Bogumil J., et al. (2008), "Evaluating administrative modernization in German local government: success or failure of the new steering model", Public administration review, vol $68, \mathrm{n}^{\circ} 5$, p. 851-863.

Lægreid P. Roness P., Rubecksen K. (2006), Modern management tools in Norvegian state agencies: regulation inside Government or Shopping basket?, Stein Rokkan centre for social studies working paper 13, 38p.

Lascoumes, P. and P. Le Galès. (2007). "From the Nature of Instruments to the Sociology of Public Policy Instrumentation", Governance 20 (1), 1-21.

Magone J. M. (2011). "The difficult transformation of state and public administration in Portugal. Europeanization and the persistence of neo-patrimonialism", Public Administration, vol 89, $\mathrm{n}^{\circ} 3$, 2011, 756-782.

Mintzberg, H. (1979). The Structuring of Organizations: A Synthesis of the Research. Prentice Hall, Englewoods Cliffs, NJ.

Noordegraaf M. (2009) "Dynamic conservatism: the rise and evolution of public management reform in the Netherlands", in Goldfinch S. Wallis J. L., eds.,International Handbook of Public Management Reform, Edward Elgar, 262-278.

OECD (1997). In search of results, performance management practices, Paris, OECD.

OECD (2005). Modernizing government: the way forward, Paris, OECD.

Ongaro E. (2011), "The role of politics and institutions in the Italian administrative reform trajectory", Public administration, 3, 738-755.

Ongaro, E. (2009). Public Management Reform and Modernization, Trajectories of Administrative Change in Italy, France, Greece, Portugal and Spain, Edward Elgar.

Poister T. H., Mc Gowan R.P. (1984), The use of management tools in municipal governement: a national survey, Public administration review, 44(3): 215-223.

Pollitt C., Bouckaert G. (2011). Public Management Reforms: an International Comparison (3rd Ed.) Oxford University Press.

Rainey H.G., Bozeman B. (2000), "Comparing public and private organizations: empirical research and the power of a priori", Journal of Public Administration Research and Theory, 10, 2, 447-469.

Self, P. (1993), Governement by the Market?The Politics of Public Choice. MacMillan

Soss, J., Fording, R., Schram, S.F. (2011) «The Organization of Discipline: From Performance Management to Perversity and Punishment », Journal of Public Adminstration Research Theory, 21 (suppl 2), 203, 232

Torres L., Pina V. Royo S. (2005), E-government and the transformation of public administration in EU countries:Beyond NPM or just a scond wave of reforms ?Documento de trabajo 2005-01 Faculdad de Ciencias economicas y empresariales.Universidad de Zaragoza, $33 \mathrm{p}$.

Walker R. M. (2007), "An empirical evaluation of innovation types and organizational and environmental characteristics: towards a configuration framework", Journal of public administration research and theory, vol 18, pp 591-615.

Wegrigh, K. (2011). 'Public Management Reform in the United Kingdom: Great Leaps, small steps and policies as their own cause', in Goldfinch S. Wallis J. L., eds.,International Handbook of Public Management Reform, Edward Elgar, 137-154.

Weishaupt J. T. (2010), «A Silent Revolution? New Public Management Ideas and the Reinvention of European Public Employment Services", Socio-Economic Review, 8, 461-486.

Yesilkagit, K. de Vries, J. (2004). 'Reform Styles of Political and Administrative Elites in Majoritarian and Consensus Democracies: Public Management Reforms in New Zealand and the Netherlands', Public Administration, 82, 4, 951-974. 